\title{
Research on Suitable Mining Technology for Placer Titanium Mines in Vietnam
}

\section{Qui-Thao LE'), Hoang NGUYEN ${ }^{1)}$, Nga NGUYEN ${ }^{1)}$, Dinh-Hieu VU', Hoa Thu-Thi LE ${ }^{1)}$, Anh Thuc-Thi NGUYEN ${ }^{3)}$, Xuan-Nam BUI ${ }^{1, *}$}

\footnotetext{
${ }^{1)}$ Hanoi University of Mining and Geology, Hanoi, Vietnam; email: lequithao@humg.edu.vn; nguyenhoang@humg.edu.vn; nguyenthihoainga@humg.edu.vn; lethithuhoa@humg.edu.vn; buixuannam@humg.edu.vn

${ }^{2)}$ Ministry of Natural Resources and Environment, Hanoi, Vietnam; email: vdhieu3@monre.gov.vn

3) Hanoi University of Natural Resources and Environment, Hanoi, Vietnam; email: thucanhvpg@gmail.com
}

http://doi.org/10.29227/IM-2020-02-11

Submission date: 06-03-2020 | Review date: 22-09-2020

\section{Abstract}

Vietnam has a potential reserve of placer titanium of around $650 \mathrm{Mt}$. The reserve lays in sandy beaches of the country from Thanh Hoa to Binh Thuan province. Placer titanium mines in Vietnam are different in geological condition, the scale of production, mining method, and environmental protection solutions, etc. Some of them are operating with inappropriate mining technology; therefore, have caused environmental issues and ineffective operation. Consequently, it is essential to have criteria for selecting appropriate mining technology to approach the sustainable development for the mines. Based on categories of geology, the scale of production, mining characteristics, requirements of safety, land reclamation and environmental protection, and mining effect, authors defined the criteria and method for selecting adequate mining technology for the placer titanium mines in Vietnam which aim for better safe, effective and sustainable. The categories to select the appropriate technology for coastal titanium placers in Vietnam including 1-feasible mining scheme, 2- mining procedure, 3- requirement volume of water, 4- slope stability, 5-environmental rehabilitation and reclamation, and 6- economic effect. The result of the application for Nam Suoi Nhum placer titanium mine in Binh Thuan province shows that the most appropriate scheme of this mine is the mining technology of using hydraulic jets, pumping and hauling by pumping mud, processing by spiral screws, and discharging by mud pumping.

Keywords: mining technology, placer titanium, sustainable development, Vietnam

\section{Potential of titanium placer in Viet Nam}

Titanium is an important mineral which is used widely in various industries. Vietnam is considered a potential country in the world thanks to the big reserve of approximately $650 \mathrm{Mt}$ (Tab. 1) (Luong Q. K. et al., 2016)

In Viet Nam, titanium placers are found along the coastal line from Thanh Hoa province to Binh Thuan province. Results from prospecting and exploration show the industrial value coastal titanium placers are located mostly in the marine sediments $(\mathrm{m})$, formed during the Middle to the Late Pleistocene, and in the marine - wind sediments ( $\mathrm{mw}$ ) of the Middle to the Late Holocene, which the length is from hundreds of meters to 20 kilometres, the width is $25-700 \mathrm{~m}$, and the thickness of 0.5-10 m (Quach D. T. et al., 2012) (Fig. 1).

The coastal titanium placers in Vietnam have similar features with sediments titanium placers in the world. They are synthetic placers, deposited by minerals with a density of 4.3-5.2 and grain size of $0.047-0.25 \mathrm{~mm}$. The majority of useful minerals includes ilmenite, rutile, zircon, and monazite in which the content of ilmenite, zircon, and rutile is $53.09-91.66 \%, 3.56-18.45 \%$, and $0.69-2.65 \%$ respectively. The extracted ore from titanium placers is qualified for export requirements (Quach D. T. et al., 2012). Fig. 2 illustrates the results of the analysis of samples from titanium placers in Binh Thuan area (Yingli L. V. et al., 2020).

According to the Decision 1546/QD-TTg dated September 3rd, 2013 signed by the Vietnamese Prime Minister on Approving the zoning plan for exploration, extraction, processing and exploitation of titanium ores by 2020, outlook to
2030, the demand of products from titanium and zircon are summarized in Tables 2 and 3.

\section{The state-of-the-art exploration of titanium placer in Viet Nam}

\subsection{Mining technology}

To date, coastal titanium placers are extracted in 23 mines from Ha Tinh to Binh Thuan (Tab. 3).

Around the world, titanium placers are now mined either by dry mining or wet concentration methods (Akinlabi S. A. et al., 2019; Bignaraj M. et al., 2019; Greg J., 2009). The dry mining scheme is the one that uses mechanical equipment of hydraulic excavator-truck, self-elevating scapers, bulldozer traps or wheel loader to excavate and transport to primary processing equipment and discharging sand. This technology is normally applied to dry deposits or to seams that are above the water level (Bignaraj M. et al., 2019; Greg J., 2009). The wet method scheme uses hydraulic equipment to excavate, such as hydraulic jets, dredgers, and excavating pumps to get ores, transporting them to primary processing equipment and discharging sand. This technology is applied to watery deposits or the seams that are under the water level (Akinlabi S. A. et al., 2019; Greg J., 2009).

Nowadays, coastal titanium placers mines in Viet Nam are using the two following mining and processing schemes:

Mining using excavators (wheel loaders) and trucks, in combination with the fixed processing complex

Ore is loaded by excavators or wheel loaders to trucks for transportation to the fixed processing complex that is located 


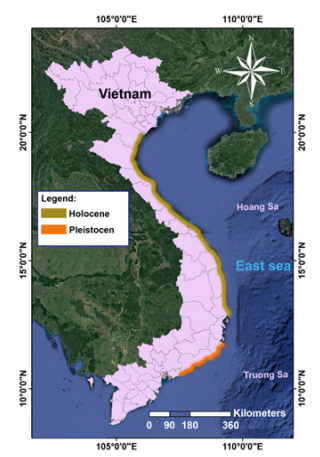

Fig. 1. Location of coastal titanium placers in Vietnam

Rys. 1. Lokalizacja przybrzeżnych podkładek okruchowego tytanu w Wietnamie

Fig. 1. Location of coastal titanium placers in Vietnam

Rys. 1. Lokalizacja przybrzeżnych podkładek okruchowego tytanu w Wietnamie

\begin{tabular}{|c|c|c|c|c|c|c|}
\hline \multirow[b]{2}{*}{ No } & \multirow[b]{2}{*}{ Areas } & \multicolumn{4}{|c|}{ Reserves and resources of useful heavy minerals $\left(10^{3}\right.$ tons) } & \multirow{2}{*}{$\begin{array}{c}\text { Total } \\
\text { zircon }\left(10^{3}\right. \\
\text { tons })\end{array}$} \\
\hline & & Reserves & 333 & $334 a$ & Total & \\
\hline 1 & Thanh Hoa & 0 & 406 & 928 & 1,334 & 92 \\
\hline 2 & Ha Tinh & 4,298 & 938 & 784 & 6,020 & 602 \\
\hline 3 & Quang Binh & 0 & 275 & 328 & 603 & 60.3 \\
\hline 4 & Quang Tri & 600 & 473 & 397 & 1,470 & 147 \\
\hline 5 & Thua Thien Hue & 568 & 3,146 & 2,383 & 6,097 & 713 \\
\hline 6 & Quang Nam & 510 & 432 & 2,587 & 3,529 & 346.3 \\
\hline 7 & Quang Ngai & 528 & 1,100 & 897 & 2,525 & 252.5 \\
\hline 8 & Binh Dinh & 3,937 & 4,235 & 612 & 8,784 & 879 \\
\hline 9 & Ninh Thuan & 4,070 & 4,300 & 4,071 & 17,226 & 1,877 \\
\hline 10 & Binh Thuan & 5,913 & 361,204 & 231,892 & 599,009 & 72,806 \\
\hline & Total & 20,424 & 376,509 & 244,879 & 646,597 & 77,116 \\
\hline
\end{tabular}

Tab. 2. Demand of products from titanium and zircon - outlook to 2030 (Decision No. 1546/QĐ-TTg, 2016) Tab. 2. Popyt na wyroby z tytanu i cyrkonu - perspektywa do 2030 r. (Decyzja nr 1546 / QĐ-TTg, 2016)

\begin{tabular}{|c|l|c|c|c}
\hline \multirow{2}{*}{ No. } & \multirow{2}{*}{ Name of product } & \multicolumn{3}{|c}{ Forecast domestic demand (10 $\mathbf{3}^{\mathbf{3}}$ tons) } \\
\cline { 3 - 5 } & & $\mathbf{2 0 1 5}$ & $\mathbf{2 0 2 0}$ & $\mathbf{2 0 3 0}$ \\
\hline 1 & Ilmenite pure ore & 1.882 & 2.081 & 2.103 \\
\hline 2 & Titanium slag & 120 & 312 & 390 \\
\hline 3 & Artificial rutile & 20 & 30 & 60 \\
\hline 4 & Reconstituted ilmenite & 20 & 30 & 60 \\
\hline 5 & Fine and superfine zirconium & 20 & 30 & 40 \\
\hline 6 & Pigment $\mathrm{TiO}_{2}$ & 90 & 150 & 200 \\
\hline
\end{tabular}

Tab. 3. Estimation of ilmenite concentration production - outlook to 2030 (Decision No. 1546/QĐ-TTg, 2016) Tab. 3. Oszacowanie stężenia ilmenitu - prognozy do 2030 r. (Decyzja nr 1546 / QĐ-TTg, 2016)

\begin{tabular}{|c|l|c|c|c|}
\hline \multirow{2}{*}{ No. Name of product } & \multicolumn{3}{|c|}{ Forecast processing output (10 } \\
\cline { 3 - 4 } tons)
\end{tabular}

in the centre of the mine, and the mixture of sand and water is pumped into the primary process system. The concentration ore collected from the primary process is reprocessed in the concentration processing component to obtain the required concentration ore (of approximately $85 \%$ of heavy minerals). (Fig. 3, where: 1 - Feeding pump of run-off mine ores, 2 - Tank for collecting run-off mine ores, 3 - Screen for separating refuse, 4 - Feeding pump for primary processing component, 5 - Feeding tank for primary processing component, 6 - Primary processing component, 7 - Tank for waste sand, 8 - Pump for removing waste sand, 9 - Feeding tank for the secondary processing component, 10 - Feeding pump for the secondary processing component, 11 - Tank for dividing into flows, 12 Secondary processing component, 13 - Water pump).

Although this technology of mining and processing offers high output, its disadvantages are a mass investment, non-conformance to small and complicated mines, and encountering difficulties in land reclamation, especially when the distance between the fixed processing complex and the mining areas is considerable. To deposits with the grades are less than $2 \%$ of heavy minerals, this technology is ineffective.

Mining using hydraulic jets and pumps, in combination with raft-mounted mobile processing complex 


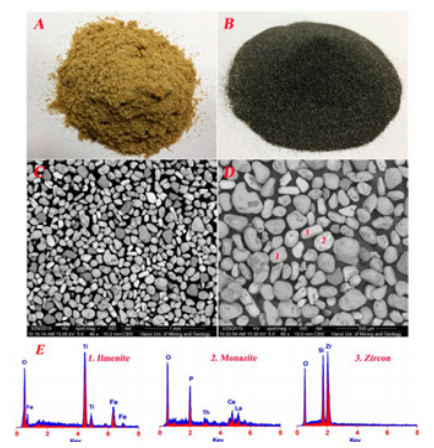

Fig. 2. Results of sample analysis of titanium placers in Binh Thuan (Yingli L. V. et al., 2020); (A) Sand sample, (B) Ore sample, (C,D) Photos of heavy minerals SEM, (E) Results

Rys. 2. Wyniki analizy próbek okruchowego tytanu w Binh Thuan

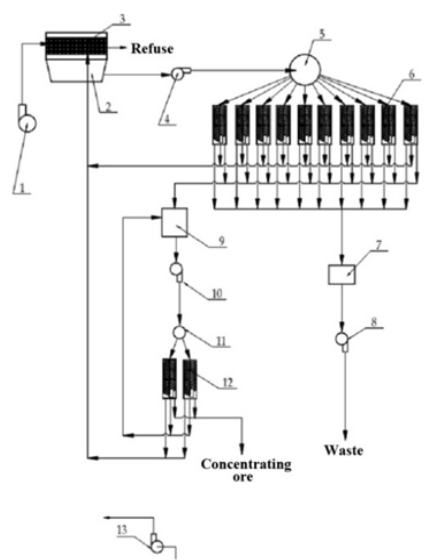

Fig. 3. The flowchart of the process scheme with the fixed processing complex (Bui X. N. et al., 2016)

Rys. 3. Schemat procesu przeróbki z stałym kompleksem przetwarzania (Bui X. N. et al, 2016)

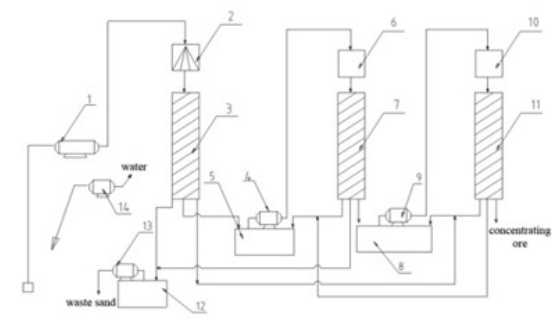

Fig. 4. The flowchart of the process scheme with mobile processing complex (Bui X. N. et al, 2016)

Rys. 4. Schemat procesu przeróbki z mobilnego kompleksem przetwarzania (Bui X. N. i in., 2016)

The ore bodies are broken by hydraulic jets (if necessary) and pumped to the raft-mounted mobile processing complex of the mine for separation into three kinds of products (tailings, intermediate ore, and concentration ore). The intermediate ore from the primary processing is pumped to the secondary processing to get the concentration ore. The qualified concentration ore (the grade of heavy minerals is higher than $85 \%)$ is pumped to the store. Waste sand is pumped to the waste dump in the mined-out areas.

This technology of mining and processing is used for sediments below the underground water level (see Fig. 4, where: 1 - Ore sand suction pump, 2 - Feeding tank with separation mechanism, 3 - Primary processing component, 4 - Intermediate processing pump, 5 - Tank for pumping to the intermediate processing component, 6 - Tank for dividing into flows, 7 - Intermediate processing component, 8 - Tank for pumping to the secondary processing components, 9 - Feeding tank for the secondary processing components, 10 - Tank for dividing into flows, 11 - Secondary processing component, 12 - Tank for pumping waste sand, 13 - Pump for removing waste sand, 14 - Water pump). The technology is currently applied in most of titanium placers mines in Vietnam.

\subsection{The disadvantages of the current mining technologies}

The inappropriate usage of mining technologies has been an impact in mining efficiency, safety and environment protection in the coastal titanium placers in Vietnam, such as:

Changing terrain of the region: during the mining and processing, the terrain of the mine area will be changed in altitude, slope, and landscape, etc. These changes create deformations of the coastlines, subsidence of the mine slopes and beaches, and flying sand, etc.

Influence on the ecosystem: Titanium mining and processing impact directly to the soil environment of the coast- 
Tab. 4. Overview of coastal titanium placers mining in Vietnam (Vietnam Department of Geology and Minerals, 2018)

Tab. 4. Przegląd wydobycia przybrzeżnego okruchowego tytanu w Wietnamie (Departament Geologii i Minerałów Wietnamu, 2018)

\begin{tabular}{|c|l|l|c|c|c|}
\hline No & \multicolumn{1}{|c|}{ Mine } & \multicolumn{1}{|c|}{ Province } & $\begin{array}{c}\text { Areas } \\
\text { (ha) }\end{array}$ & $\begin{array}{c}\text { Reserves } \\
\text { (tons) }\end{array}$ & $\begin{array}{c}\text { Output } \\
\text { (tons per year) }\end{array}$ \\
\hline 1 & Ky Khang & Ha Tinh & 759 & $1,567,000$ & 64,700 \\
\hline 2 & Cam Xuyen & Ha Tinh & 1,595 & $1,019,000$ & 68,000 \\
\hline 3 & Sen Thuy & Quang Binh & 382.8 & 217,596 & 13,000 \\
\hline 4 & Dong Luat & Quang Tri & 75.2 & 121,189 & 143,100 \\
\hline 5 & Vinh Tu & Quang Tri & 118 & 102,283 & 8,413 \\
\hline 6 & Hai Khe & Quang Tri & 241,8 & 172,293 & 10,000 \\
\hline 7 & Gio Linh & Quang Tri & 156.83 & 66,206 & 5,560 \\
\hline 8 & Quang Ngan & Thua Thien Hue & 288.2 & 376,305 & 30,000 \\
\hline 9 & Phu Dien & Thua Thien Hue & 90 & 568,735 & 31,500 \\
\hline 10 & My Thanh 1 & Binh Dinh & 242.8 & 736,732 & 52,500 \\
\hline 11 & My Thanh 2 & Binh Dinh & 173.26 & 326,076 & 26,250 \\
\hline 12 & My Thanh 3 & Binh Dinh & 179.92 & 322,110 & 24,150 \\
\hline 13 & My An & Binh Dinh & 180.69 & 179,454 & 14,000 \\
\hline 14 & Nam De Gi & Binh Dinh & 150 & 334,597 & 35,000 \\
\hline 15 & Tu Hoa - Tu Thien & Ninh Thuan & $1,132.5$ & $3,929,646$ & 199,500 \\
\hline 16 & Son Hai & Ninh Thuan & 1,033 & $3,329,312$ & 118,904 \\
\hline 17 & Thien Ai 1 & Binh Thuan & 64.5 & 44,617 & 3,186 \\
\hline 18 & Thien Ai 2 & Binh Thuan & 356.45 & 218,000 & 24,000 \\
\hline 19 & Vung Mon & Binh Thuan & 23,968 & 90,049 & 11,025 \\
\hline 20 & Long Son - Suoi Nuoc 1 & Binh Thuan & 807.2 & $2,234,875$ & 213,900 \\
\hline 21 & Long Son - Suoi Nuoc 2 & Binh Thuan & 156.4 & 378,994 & 43,490 \\
\hline 22 & Mui Da & Binh Thuan & 224 & 148,069 & 70,000 \\
\hline 23 & Nam Suoi Nhum & Binh Thuan & 515.5 & $2,343,159$ & 117,345 \\
\hline
\end{tabular}

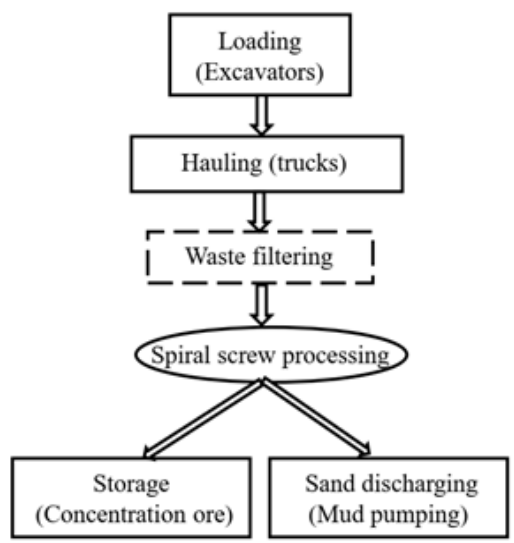

Fig. 5. The flowchart of the mining technology using excavator and trucks, spiral screw processing and mud pumping Rys. 5. Schemat technologii górniczej z wykorzystaniem koparki i ciężarówek, obróbki ślimakowej i pompowania szlamu.

al areas. The waste sand volume and backfill areas occupy a small percentage in comparison to the excavated areas.

Impact on the water environment: Rivers and lakes surrounding the mining areas are the main water suppliers to the mining and processing. The underground water in the sand is circularly used. However, the mining and processing activities have lowered the local water level, causing salt incursion into water-bearing aquifers.

Loss of mineral resources: The usage of inappropriate mining technology is the reason for natural resources lost and low recovery.

Radioactive pollution: Mining, hauling, and processing of ilmenite can disseminate radioactive substances from accompanying minerals, such as zircon and monazite, containing Thorium, or Uranium. It is worth noting that concentration ores contain a higher grade of radioactive than safety standards.

3. Categories in the selection of mining technologies for coastal titanium placers in Vietnam

\subsection{Feasible mining technologies}

Derived from the two above-mentioned mining technologies, the following technologies are feasible for coastal titanium placers in Vietnam. They are:
Mining with excavators and trucks, processing by spiral screws, and pumping mud (Scheme No.1)

This technology is applied for any productivity of mine that the water supply is not abundant, technological conditions for an internal waste dump are not supportive. An external waste dump which is close to the primary processing station is helpful in this case (Fig. 5).

At the primary processing station, sandy ore is separated from the garbage and gravel by rotation screening or inclined vibrating screening, running off to the sandy mud hole afterwards. Sandy mud is pumped to the ore tank of the processing station, continuously pumped to spiral screws. The levels of spiral screws are assembled depending on the separation feasibility of the raw ore and the grade of the useful heavy minerals. A clutch separator can be installed before spiral screws. However, it requires a stable feeding of ore, and therefore, is rarely used due to difficulties in operation, low recovery and promotion of the secondary processing. The output of the processing component is concentration ore and waste sand. Waste sand is pumped into the waste dump through the mud pipeline system. In case water is circulated, the mining scheme is illustrated in Fig. 6, where: 1 - Mine site; 2 - Excavator; 3 - Truck; 4 - Tank with garbage filter mechanism; 5 - Pumping mud hole; 6 - Spiral scews stations; 7 - Mud pipe- 

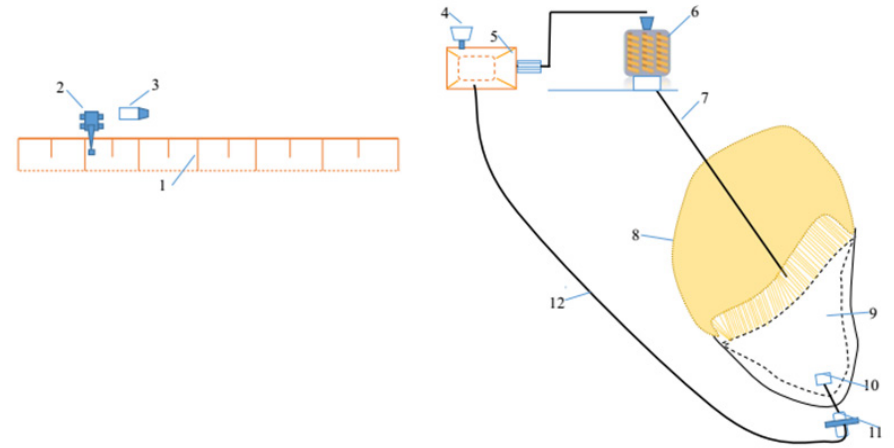

Fig. 6. The flowchart of the mining technology with excavator and trucks, processing by spiral screws and pumping mud (water circulation) Rys. 6. Schemat technologii górniczej z koparką i ciężarówkami, obróbka śrubami spiralnymi i pompowanie szlamu (cyrkulacja wody)

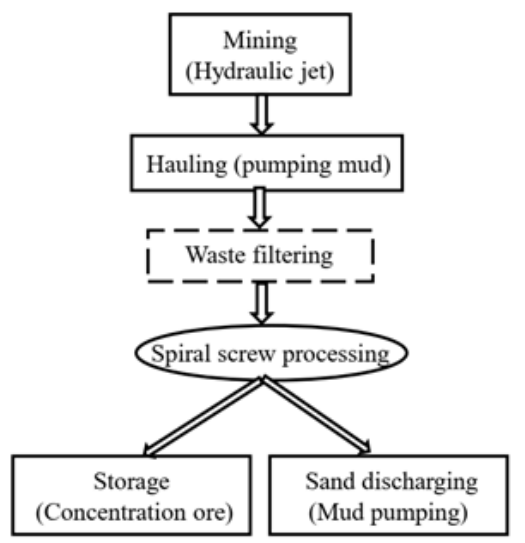

Fig. 7. Principle of mining by hydraulic jets, suction and hauling by pumping, processing by spiral scews and discharging mud by pumping Rys. 7. Zasada urabiania strumieniami hydraulicznymi, zasysania i wyciągania przez pompowanie, przeróbka za pomocą ślimaków spiralnych i odprowadzanie szlamu przez pompowanie

Fig. 8. The flowchart of mining by hydraulic jets, pumping and hauling by pumping mud, processing by spiral screws, discharging mud by pumping (division mining)

Rys. 8. Schemat urabiania strumieniami hydraulicznymi, pompowania i ciągnięcia przez pompowanie szlamu, przeróbki ślimakami spiralnymi, odprowadzania szlamu przez pompowanie (eksploatacja z podziałami).

line; 8 - Filled waste dump; 9 - Spare waste dump; 10 - Water filter well; 11 - Water circulation pumping station; 12 - Water circulation pipeline

Mining by hydraulic jets, suction and hauling by pumping mud, processing by spiral screws, and discharging mud by pumping (Scheme No. 2)

Scheme No. 2 differs from the scheme No. 1 by the combination of hydraulic jets and pumping mud (Fig. 7). This is the popular scheme in coastal titanium placers, especially in areas with abundant water resources and difficulties in directly sucked by pumping mud (see Fig. 8 , where: 1 - Hydraulic jets; 2 - Spiral screws station; 3 - Feeding mud hole; 4 - Water pipeline; 5 - Water circulation pumping station; 6 - Water pipeline from filter well; 7 - Pressure water pipeline for hydraulic jets; 8 - Waste dump filter well; 9 - Temporary waste dump of the first mining division; 10 - Waste mud pipeline; 


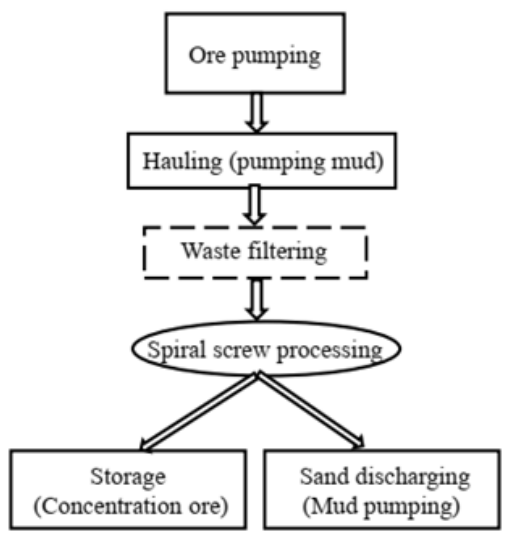

Fig. 9. The flowchart of the mining technology using ore pumping, spiral screw processing and mud pumping Rys. 9. Schemat blokowy technologii wydobycia z wykorzystaniem pompowania rudy, przeróbki ślimakowej i pompowania płuczki

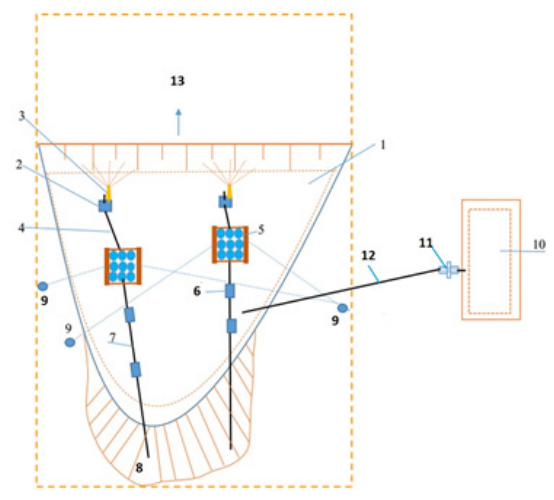

Fig. 10. The flowchart of mining by ore pumping, processing by spiral screws, and discharging mud by pumping

Ryc.10. Schemat blokowy wydobycia przez pompowanie rudy, przetwarzanie za pomocą ślimaków spiralnych i odprowadzanie mułu przez pompowanie

11 - Internal waste dump; 12 - Mud pumping hole in the mine site; 13 - Feeding pump to spiral screws; 14 - Mining site; 15 - Mining order of different division).

Mining by ore pumping, processing by spiral screws, and discharging mud by pumping (Scheme No. 3)

This is the simplest mining technology, which is used in small titanium placers in white sand seams or grey sand seams that are not thick (Fig. 9).

In this mining technology, the ore mud pumping is put on the floatation to pump the sandy mud at the lower level and the run-off sand. High-pressure hydraulic jets support to pump into the crest to dilute the mud concentration for a better ore pumping. The ore mud is transported by the pipeline to the primary spiral screws station of the mine site. Discharged sand is pumped into the mined areas by the mud sand pipeline (see Fig. 10, where: (1 - Ore mud pumping hole; 2 - Pumping raft; 3 - Hydraulic jets (if necessary); 4 - Ore sand pipeline; 5 - Spiral screws station; 6-Floatation; 7 - Waste sand pipeline; 8 - Internal waste dump; 9 - Fixed bolts of spiral srcew station; 10 - Backup water hole; 11 - Water auxiliary pump; 12 - Water auxiliary hauling pipeline; 13 - The next mining area).

\subsection{Mining approach}

It is critically important in defining the appropriate mining approach in surface mining, especially in coastal titanium placers in Vietnam. Suitable mining technology does not only ensure the effective and safe mining operation but also support sand discharge and reclamation, partly contributing to the natural recovery and environmental protection. The following methods are proposed to the coastal placers titanium mines in Vietnam.

\subsubsection{Longitudinal mining order}

The mining procedure is alternated in the longitudinal axis of the mine, from the first block to the last one (Fig. 11).

Horizontal mining order

By this mining order, the procedure is alternated in the horizontal axis of the mine (Fig. 12).

\subsubsection{Mining order en éventail}

This mining order is applied for complex-shape mines, alternately for en éventail blocks (Fig. 13).

\subsection{Requirement of water}

The required volume of water and the ratio of water recovery

Either in dry mining or wet concentration methods, water is used to transform the titanium placers to mud sand, transporting them to the spiral screw raft. The required annual volume of a mine for the planned output is defined after the formula $\mathrm{Q}=$ Aq.q.[1+(100\% - Kth $)]$, m3/year. In which: Aq 


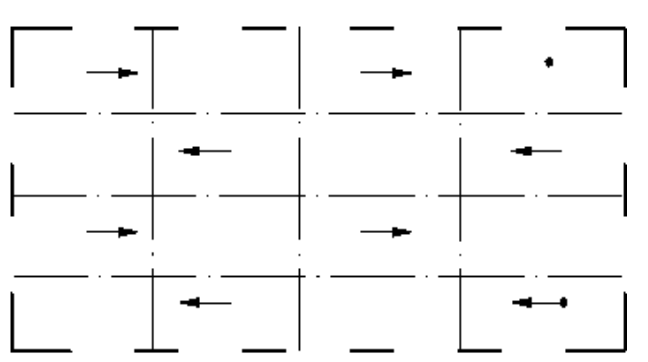

Fig. 11. Longitudinal mining order Rys. 11. Wzdłużny porządek wydobycia

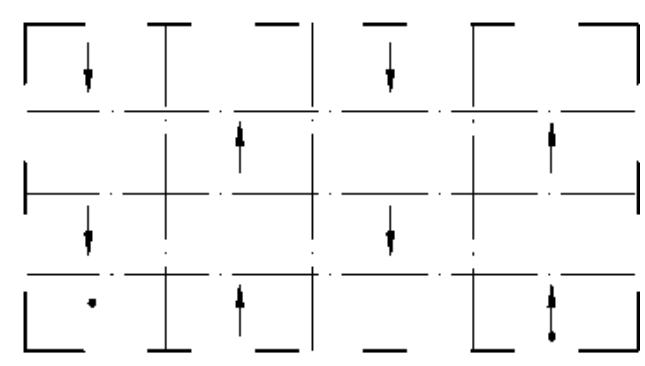

Fig. 12. Horizontal mining order

Rys. 12. Pozioma kolejność wydobycia

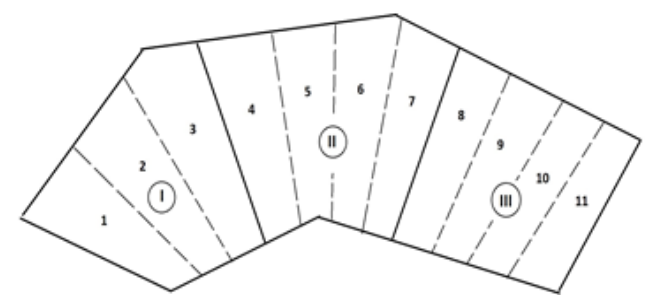

Fig. 13. Mining order of en éventail blocks

Rys.13. Kolejność wydobywania bloków wachlarzowych

- Annual ore of output, $\mathrm{m}^{3} /$ year; $\mathrm{q}$ - Index of water consumption in mining, $\mathrm{m}^{3} / \mathrm{m}^{3}$; Kth - Ratio of water recovery, \%.

The relationship between the ratio of water recovery in ore with variable contents of clay $(5 \%, 10 \%, 15 \%$ and $20 \%)$ and the changes in moisture of ore $(0 \%, 15 \%, 30 \%)$ is shown in Figs. $14-17$.

\section{Water consumption}

In above-mentioned mining technologies for coastal titanium placers in Vietnam, there is only one phase of the scheme No. 1 (using excavator and trucks) that does not use water. Other phases of this scheme (primary processing and sand discharge) and all phases of schemes No. 2 and No. 3 use waterpower. The necessary volume of water to maintain the mining operation depends on many factors, such as clay content in the ore, the moisture of ore, the ratio of water recovery in the mining, and the mine output, etc.

From actual water consumption at coastal titanium placers in Vietnam, authors defined the real water consumption of mines schemes No. 1, No. 2 and No. 3 are $\mathrm{q} 1=1,35 \mathrm{~m} 3 / \mathrm{m} 3$, $\mathrm{q} 2=1,62 \mathrm{~m}^{3} / \mathrm{m}^{3}$ và $\mathrm{q} 3=1,95 \mathrm{~m}^{3} / \mathrm{m}^{3}$, respectively.

\subsection{Slope stability}

Due to the complexity of impact factors to define the slope stability, such as underground water, evaluation methods, and sliding surface position, Slope/W (Geoslope) software is used to calculate the slope stability in mining at coastal titanium placers with bench height of above $90 \mathrm{~m}$ (Fig. 18). The relationship between the slope stability coefficient and face angle in accordance with the bench height of $90 \mathrm{~m}$ in coastal titanium placers in Vietnam is illustrated in Fig. 19.

\subsection{Environmental rehabilitation and reclamation}

Fig. 20 illustrates the procedure of mining, discharge, and reclamation in blocks for coastal titanium placers in Vietnam.

Waste sand dunes are moved by movers, which the height after the mover is equal to the natural height of the area. On the whole moved area, plants which are suitable to the natural conditions, such as a windbreak, pine and acacia are planted. The number of plants is 660 trees/hectare. Plants and trees are taken good care in 3 years till the trees are normally developed. In case if any trees are dead, new trees are planted to assure the density of mining in the rehabilitation and reclamation areas (Decision 38/2005/QD-BNN, 2005).

The cost of environmental reclamation, on average, for the coastal titanium placers in Vietnam is estimated at 45.5 million VND (approximately 2,000 USD) for 1 ha sandy waste dump.

The procedure of mining, discharge and reclamation of blocks in coastal titanium placers in Vietnam is shown in Fig. 


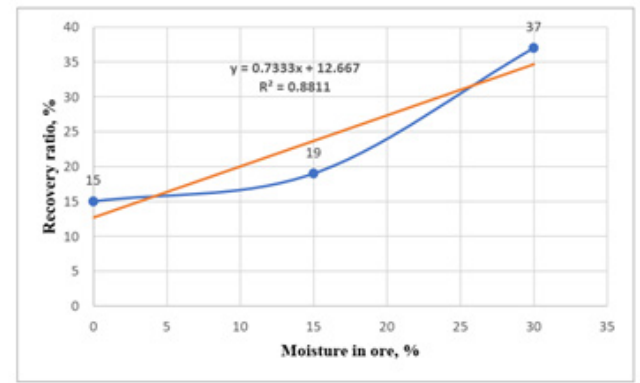

Fig. 14. The relationship between the ratio of water recovery in ore of $5 \%$ clay and the moisture change of ore $(0 \%, 15 \%, 30 \%)$ Rys. 14. Zależność między stosunkiem odzysku wody w rudzie 5\% gliny a zmianą wilgotności rudy $(0 \%, 15 \%, 30 \%)$

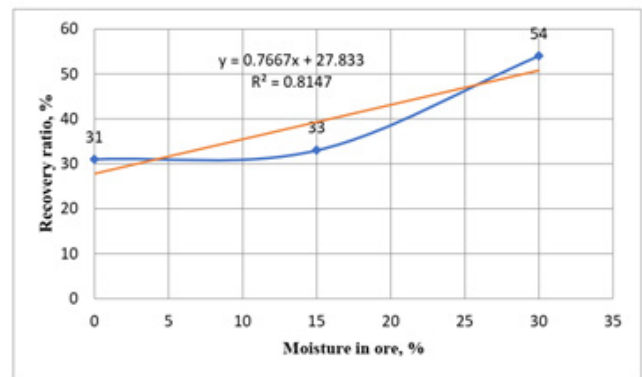

Fig. 15. The relationship between the ratio of water recovery in ore of $10 \%$ clay and the moisture change of ore $(0 \%, 15 \%, 30 \%)$ Rys. 15. Zależność między stosunkiem odzysku wody w rudzie $10 \%$ gliny a zmianą wilgotności rudy $(0 \%, 15 \%, 30 \%)$

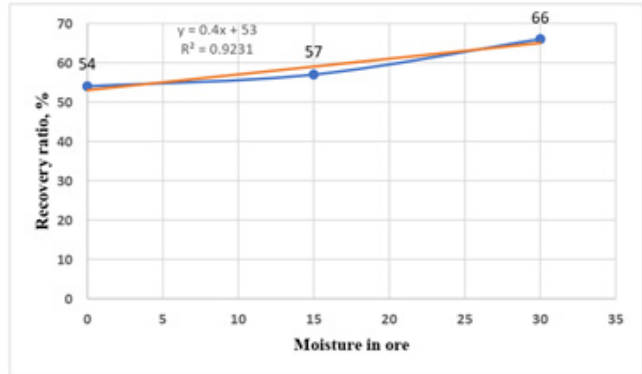

Fig. 16. The relationship between the ratio of water recovery in ore of $15 \%$ clay and the moisture change of ore $(0 \%, 15 \%, 30 \%)$ Rys. 16. Zależność między stosunkiem odzysku wody w rudzie $15 \%$ gliny a zmianą wilgotności rudy $(0 \%, 15 \%, 30 \%)$

21, where: 1-4 - Mine - out blocks have been recalled; 5 Block for sand discharge; 6 - Current mining block; 7-9 - the following blocks to mine.

\subsection{Economic effect}

The economic effect is a required factor to evaluate and select appropriate mining methods for coastal titanium placers in Vietnam. Although there are many methods to evaluate the economic effect, however, the basic formula is based on the estimated costs of each specific scheme.

1. Basic investment cost $(\mathrm{C}): \mathrm{C}=\mathrm{Ca}+\mathrm{Cb}, \mathrm{VND}$. Where: $\mathrm{Ca}$ - Total cost of equipment purchase, assemble, spare parts and overhaul, VND; Cb - Infrastructure building cost, VND.

2. Annual production cost $(\mathrm{E}): \mathrm{E}=\mathrm{Efc}+\mathrm{Evc}, \mathrm{VND} /$ year. Where: Efc - fixed costs: depreciation, fixed salary, and social insurance, $\mathrm{VND}$ /year; Evc - variable costs: energy, materials, tax and fees, etc., $\mathrm{VND} /$ year.

3. Revenue (R): $\mathrm{R}=\mathrm{An} \times \mathrm{P}, \mathrm{VND} /$ year. Where: An - Annual output of raw ore after excavation, $\mathrm{t} /$ year; $\mathrm{P}$ - Price of a ton of raw ore, $\mathrm{VND} / \mathrm{t}$.
4. Gross Profit (GP): GP = R - E, VND/year. Where: R - Annual revenue, VND/năm; E - Annual production cost, $\mathrm{VND} /$ year.

5. Net Profit (NP): NP = GP - T $\neg$, VND/year. Where: GP - Gross Profit, VND; T - income tax, T $\neg=0.25 \times$ GP, VND.

6. Equity (EI): EI = NP / C. Where: $\mathrm{NP} \neg$ - Net Profit of the mine, $\mathrm{VND}$; $\mathrm{C}\urcorner$ - Basic investment cost, VND.

After calculation, the mining scheme of maximum of equity $(\mathrm{EI}>0)$ is selected to apply.

\section{The selection of appropriate technology to coastal titani- um placers in Vietnam}

From the six above-mentioned categories, the selection of appropriate technology of coastal titanium placers in Vietnam are as followed:

Step 1: Input data of geological and hydrogeological conditions, quality of sands ore, expected output, the shape of mine and other relevant economic - technological indexes.

Step 2: Proposing 3 mining schemes No. 1, No. 2 and No. 3 to the mine with detail information on technology and equipment. 


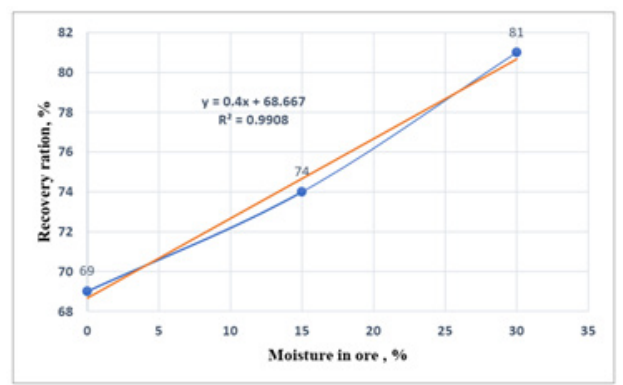

Fig. 17. The relationship between the ratio of water recovery in ore of $20 \%$ clay and the moisture change of ore $(0 \%, 15 \%, 30 \%)$ Rys. 17. Zależność między stosunkiem odzysku wody w rudzie $20 \%$ gliny a zmianą wilgotności rudy $(0 \%, 15 \%, 30 \%)$

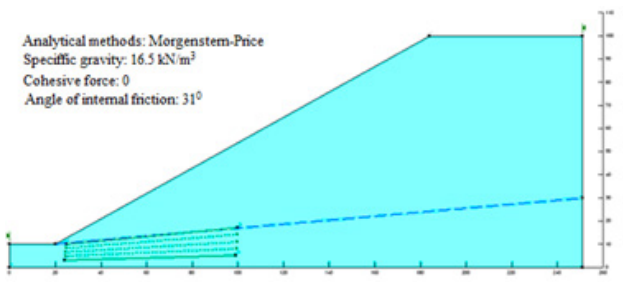

Fig. 18. Model of slopes by Slope/W software

Rys. 18. Model zboczy za pomocą oprogramowania Slope / W

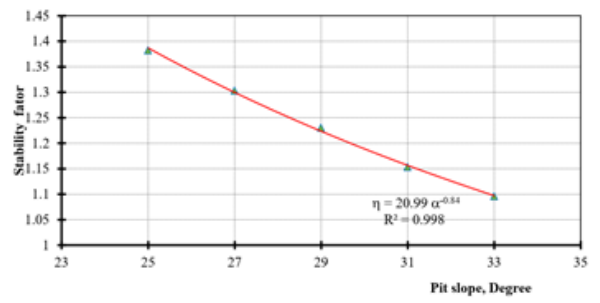

Fig. 19. The relationship between the slope stability coefficient and the face angle in accordance with the bench height of $90 \mathrm{~m}$ Rys. 19. Zależność między współczynnikiem stateczności a kątem nachylenia w zależności od wysokości zboczy $90 \mathrm{~m}$

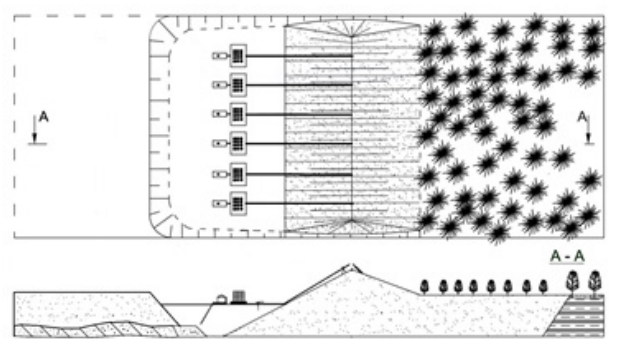

Fig. 20. The relationship between mining, discharge and reclamation of environment for the coastal titanium placers in Vietnam (Dang T. T. et al., 2008) Rys. 20. Zależność między wydobyciem, odpadami i rekultywacją środowiska dla przybrzeżnych osadników okruchowego tytanu w Wietnamie (Dang T. T. et al, 2008)

Step 3: Define suitable mining order (longitudinal order, horizontal order, or order of en éventail blocks) while applying the schemes No. 1, No. 2 and No. 3.

Step 4: Evaluate the capacity of water supply to requirement volume water as requested by schemes No. 1, No. 2 , and No. 3 .

Step 5: Check the slope stability conditions by schemes No. 1, No. 2, and No. 3.

Step 6: Check the conditions for environmental rehabilitation and restoration by schemes No. 1, No. 2, and No. 3 .

Step 7: Evaluation of economic effects of schemes No. 1, No. 2, and No. 3.
Step 8: Select the scheme that maximizes EI $(E I>0)$. This is the appropriate mining technology for the mine.

The flowchart of the selection of appropriate technology to coastal titanium placers in Vietnam is shown in Fig. 22.

\section{Pilot calculation to the coastal titanium placers Nam Suoi Nhum, Binh Thuan, Vietnam}

The mine Nam Suoi Nhum is in Binh Thuan province, occupying the following information: the deposit is distributed in marine sediment of Pleistocene; the seam thickness is 78 $\mathrm{m}$; the content of clay is $13-15 \%$; the deposit is located at unfavorable condition of hydrogeology; the reserve of mine 


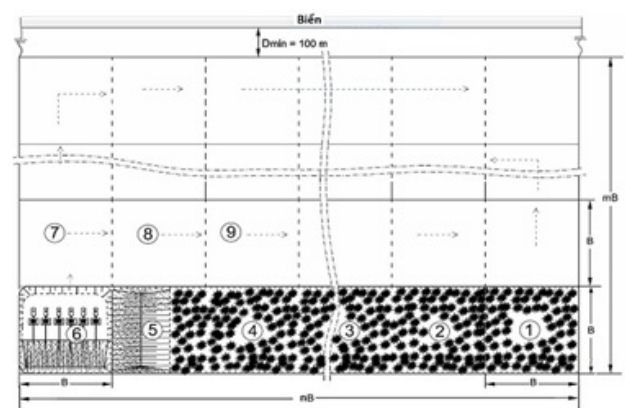

Fig. 21. Procedure of mining, discharge and reclamation of blocks in coastal titanium placers in Vietnam (Dang T. T. et al., 2008) Rys. 21. Procedura wydobywania i rekultywacji bloków w przybrzeżnych osadnikach okruchowego tytanu w Wietnamie (Dang T. T. et al, 2008)

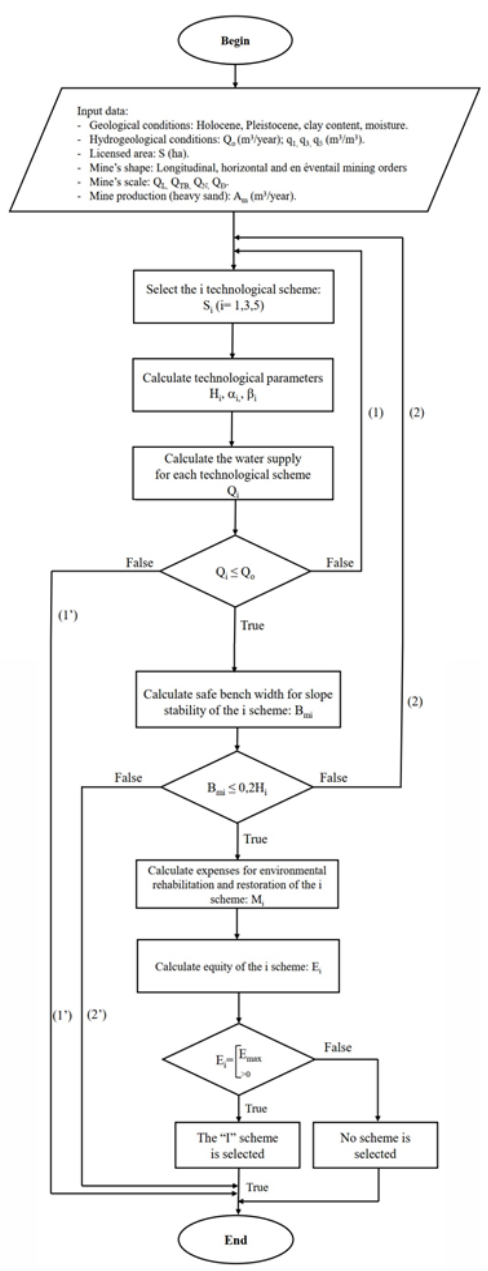

Fig. 22. The flowchart of the selection of appropriate technology to coastal titanium placers in Vietnam Ryc.22. Schemat doboru odpowiedniej technologii wydobywczej przybrzeżnego okruchowego tytanu w Wietnamie

is $2,343,159$ tons of ore (approximately $142,170,224 \mathrm{~m} 3$ sands ore); the licensed area for mining is en éventail of 514.4 ha; the mine production is 117,345 tons per year (raw ore), approximate $7,110,000 \mathrm{~m} 3 /$ year (ore sands); the life of mine is 23 years; the annual working days are 300 days, 2 working shift per day, and 8 working hour per shift.

The calculation of the 8 steps above shows these results:

1. Nam Suoi Nhum mine can apply all three schemes of No. 1, No. 2 and No. 3 with the current natural and technological conditions.

2. With the licensed mine shape, the better procedure is en éventail mining.
3. The requirement volume of water in schemes No. 1, No. 2 and No. 3 are 11,998,120 m3, 14,973,660 m3 and 18,578,430 m3 per year, respectively. However, the volume of water that the mine can supply at the current hydrogeological conditions is $15,181,800 \mathrm{~m} 3$ per year. Thus, the mining scheme No. 3 is unappropriated to Nam Suoi Nhum mine.

4. The mining schemes No. 1 and No. 2 meet the safety conditions of the face angles of the slop (34o), and overall slope angle (29-31o).

5. Both schemes ensure environmental rehabilitation and reclamation of 514,4 ha after mining, the obedience of the Law on Environmental Protection. 
6. The equity of schemes No. 1 and No. 2 are 0.11 and 0.42, respectively. Consequently, the mining scheme No. 2 (the mining technology of using hydraulic jets, pumping and hauling by pumping mud, processing by spiral screws, and discharging by mud pumping) is the appropriate technology for the coastal titanium placers in Nam Suoi Nhum.

\section{Conclusion}

Vietnam has a potential reserve of coastal titanium placers. However, mines here have not been effective operating, facing challenges in safety, loss of resource and negative impacts on the environment due to inappropriate mining technology.

The article offers 6 categories to select the appropriate technology for coastal titanium placers in Vietnam, including (i) necessary conditions: 1 - feasible mining scheme, 2 - mining procedure, 3 - requirement volume of water, 4 - slope sta- bility, 5 - environmental rehabilitation and reclamation; and (ii) a sufficient condition: 6 - economic effect.

A pilot calculation is applied to Nam Suoi Nhum placer titanium mine in Binh Thuan province, showing that the most appropriate mining scheme is the scheme No. 2 (the mining technology of using hydraulic jets, pumping and hauling by pumping mud, processing by spiral screws, and discharging by mud pumping) because it has maximal equity ( 0.42 in comparison with the equity of remaining scheme is 0.11 ).

The above mentioned criteria and procedures can be applied also for other coastal titanium placers in Vietnam and in other mines with similar conditions of geology and hydrogeology.

\section{Acknowledgement}

This study is funded by Hanoi University of Mining and Geology through the research project T20-15. 


\title{
Literatura - References
}

1. Akinlabi S. A. et al (2019), "Titanium and epoxy for automobile application: a review".

2. Bui X. N. and Ho S. G. (2016), "Status of Development Orientations for Mining Titanium Placers in Vietnam", Mining Science and Technology, (1), p. 40-50.

3. Bignaraj M. et al (2019), "Preparation of nanomaterials from strategic placer heavy minerals recovered from red sediments of badlands topography along the southeast coast of India", Current Science. 116(8), p. 1363.

4. Dang T. T. and Bui X. N. (2008), "Research of the process parameters and suitable mining sequence of ilmenite ore (Ti) in coastal sand dunes", Journal of Mining Industry, Vol 06, p. 24-29.

5. Decision 38/2005/QĐ-BNN Ministry of Agriculture and Rural Development, promulgating economic and technical norms for afforestation, zoning off to promote forest regeneration and forest protection.

6. Decision No. 1546/QĐ-TTg of September 2016 approving the master plan on zoning of areas for exploration, mining, processing and use of titanium ore through 2020, with a vision toward 2030.

7. Greg J. (2009), "Mineral sands: An overview of the industry", Unpublished. Capel: Iluka Resources Limited.

8. Luong Q. K. and Khuong T. H. (2016), Distribution and potential of the titanium, zircon and rare earth minerals in the coastal placer, South Suoi Nhum, Binh Thuan province", J. Min. Earth Sci. Vol. 54, p. 56-65.

9. Quach D. T., Trinh P. T., Hoang C. P. (2012). “Titanium placers in the red sand dunes in Binh Thuan province and measures for managing sustainable mining and processing", Proceedings of the 2nd International Conference on Advances in Mining and Tunneling, p. 154-156, Hanoi, Vietnam.

10. Vietnam Department of Geology and Minerals (2018), Licenses of titanium mining, Hanoi.

11. Yingli L. V. et al (2020), "A Comparative Study of Different Machine Learning Algorithms in Predicting the Content of Ilmenite in Titanium Placer", Applied Sciences. 10(2), p. 635.

\begin{abstract}
Dobór odpowiedniej technologii eksploatacji okruchowego tytanu w Wietnamie
Wietnam ma potencjalne rezerwy okruchowego tytanu w wysokości około $650 \mathrm{Mt}$. Rezerwat leży na piaszczystych plażach kraju od Thanh Hoa do prowincji Binh Thuan. Kopalnie okruchowego tytanu w Wietnamie różnią się stanem geologicznym, skala produkcji, sposobem wydobycia, rozwiązaniami w zakresie ochrony środowiska itp. Niektóre z nich działaja na niewłaściwej technologii wydobywczej, w związu z czym spowodowały problemy środowiskowe i nieefektywna eksploatację. W zwiąku $z$ tym niezbędne jest posiadanie kryteriów doboru odpowiedniej technologii wydobywczej do podejścia do zrównoważonego rozwoju. W oparciu o kategorie geologiczne, skalę produkcji, charakterystykę górnicza, wymagania bezpieczeństwa, rekultywacji gruntów i ochrony środowiska oraz efektu górniczego, autorzy określili kryteria i sposób doboru odpowiedniej technologii wydobycia dla stacjonujących kopalni tytanu $w$ Wietnamie, które maja na celu zwiększenie bezpieczeństwa, efektywne i trwate. Te kategorie obejmuja 1- wykonalny schemat wydobycia, 2- procedurę wydobycia, 3-wymagana ilość wody, 4- stateczność zboczy, 5-rekultywację środowiska oraz 6-efekt ekonomiczny. Wynik zastosowania dla kopalni okruchowego tytanu Nam Suoi Nhum w prowincji Binh Thuan pokazuje, że najbardziej odpowiednim schematem tej kopalni jest technologia wydobywcza wykorzystujaca strumienie hydrauliczne, pompowanie i ciagnięcie przez pompowanie szlamu, przetwarzanie za pomoca śrub spiralnych i odprowadzanie przez pompowanie błota.
\end{abstract}

Słowa kluczowe: technologia górnicza, złoże okruchowego tytanu, zrównoważony rozwój, Wietnam 